\title{
EFFECTS OF DIGESTIBLE PROTEIN TO ENERGY RATIOS ON GROWTH AND CARCASS CHEMICAL COMPOSITION OF SIAMESE FIGHTING FISH (Betta splendens)
}

\author{
Efeito da relação energia: proteína digestível no crescimento e composição química de \\ carcaça em dietas para alevinos de Betta splendens
}

\author{
Marcos Vinicius Antunes de Lemos ${ }^{1}$, Thiago Quirino Arantes ${ }^{1}$, Cristielle Nunes Souto ${ }^{1}$, \\ Graciela Pessoa Martins ${ }^{1}$, Janaína Gomes Araújo ${ }^{2}$, Igo Gomes Guimarães ${ }^{3}$
}

\begin{abstract}
The expansion in the market of ornamental fish depends on the intensification of production systems and the generation of appropriate technologies. Therefore, it is necessary to know the nutritional requirements of each species for the formulation of nutritionally balanced diets. A 30-day feeding trial was undertaken to evaluate the effects of different dietary digestible protein to energy ratio in diets for Betta splendens fingerlings. Fifty-six all-male $B$. splendens with $1.03 \pm 0.11 \mathrm{~g}$ average weight were randomly stocked into $561 \mathrm{~L}$-aquaria in a completely randomized design with a 2 x 4 factorial arrangement, comprising eight treatments and seven replication. Each fish was considered an experimental unit. Diets were formulated to contain 28.0, 35.0, 42.0 and 49.0\% DP and 3,600 and 3,200 kcal/kg DE. The growth parameters evaluated in this trial were weight gain (WG), feed intake (FI), feed conversion ratio (FCR), protein efficiency ratio (PER) and specific growth rate (SGR). No difference $(\mathrm{P}>0.05)$ was observed for WG, FCR and SGR. However, a higher FI was observed for fish fed diets containing $42.0 \% \mathrm{DP}(\mathrm{P}<0.05)$. A positive effect of DP and DE on PER was observed in this study. Generally, according to the increase of DE levels, a reduction on PER was observed. Based on this experimental condition, we recommend the use of $28.0 \%$ DP and 3,200 kcal $/ \mathrm{kg}$ DE in diets for B. splendens.
\end{abstract}

Index terms: Protein requirement, ornamental fish, carcass composition, energy requirement, growth.

\section{RESUMO}

A expansão no setor produtivo de peixes ornamentais depende da intensificação dos sistemas de produção e da geração de tecnologias adequadas. Por isso, é necessário o conhecimento das exigências nutricionais de cada espécie para a formulação de rações nutricionalmente adequadas. Neste estudo, objetivou-se avaliar as diferentes relações energia:proteína digestível em dietas para alevinos de Betta splendens. O experimento teve a duração de 30 dias, sendo utilizados 56 alevinos machos de $B$. splendens com peso médio inicial de $1,03 \pm 0,11 \mathrm{~g}$. O delineamento experimental utilizado foi o inteiramente casualisado em arranjo fatorial, sendo composto por oito tratamentos e sete repetições, considerando-se um peixe como uma unidade experimental. Foram formuladas dietas práticas, cujos níveis de proteína digestível foram 28,$0 ; 35,0 ; 42,0$ e $49 \%$ e os níveis de energia digestível de 3.200 e $3.600 \mathrm{kcal} / \mathrm{kg}$. Os parâmetros de desempenho produtivo avaliados foram: ganho em peso (GP), consumo de ração aparente (CRA), conversão alimentar aparente (CAA), taxa de eficiência protéica (TEP) e taxa de crescimento especifico (TCE). Não houve diferença significativa entre os tratamentos para GP, CAA, TCE, entretanto foi observado maior CRA para o nível de PD de 42\% $(\mathrm{P}<0,05)$. A TEP apresentou diferença significativa, de maneira que quanto maior o nível de energia digestível menor a taxa de eficiência protéica. Com base nas condições experimentais deste estudo e na taxa de eficiência protéica, o melhor nível de PD e ED para melhor taxa de eficiência protéica foi de $28 \%$ e $3200 \mathrm{kcal} / \mathrm{kg}$ ED, respectivamente.

Termos para indexação: Exigências protéicas, peixe ornamental, composição da carcaça, requerimentos energéticos, crescimento.

\section{INTRODUCTION}

Ornamental fish culture is an increasingly growing aquaculture activity in developing countries. This market has been increasing since the 80's with annual profits around U\$ 900 million with fish marketing and three billion dollars with related equipments and feed with a growing rate around $14 \%$ since 1985 . The Asian countries are responsible for more than half of worldwide production in this activity while the main consumers are the USA, Japan and European Union, particularly Germany, France and United Kingdom (Food and Agriculture Organization of the United Nations - FAO, 2007; Panné; Luchini, 2008).

Although the economical importance of ornamental fish production, few information are available on nutrient requirements for the species usually kept in aquaria and most of the recommendations are based on food fish studies (Yanong, 1999; Blom; Dabrowski, 2000; Sales; Jansen, 2003). Thus, a great diversity of ornamental fish species

\footnotetext{
${ }^{1}$ Universidade Federal de Goiás/UFG - Jataí - GO - Brasil

2Universidade Federal de Goiás/UFG - Goiânia - GO - Brasil

3Universidade Federal de Goiás/UFG - Departamento de Zootecnia - Campus Jataí - Cx. P. 03 - 75800-000 - Jataí - GO - Brasil - igoguimaraes@gmail.com Received in july 2, 2013 and approved in november 22, 2013
}

Ciênc. Agrotec., Lavras, v.38, n. 1, p.76-84, jan./fev., 2014 
with different feeding plasticity is fed with the same diet, leading to an increased cost of production and the excretion of nutrients to the water.

Besides the important role of protein for adequate growth and maintenance of fish, this nutrient is either responsible for most of the production cost of a formulated diet (Robinson; Li, 1997). The protein and energy content of a diet are closely related and there are several reports on the influence of both factors on growth and feed utilization of fish (Garling; Wilson, 1976; El-sayed; Teshima, 1992; Ai et al., 2004). If the dietary energy content of a diet is not sufficient to meet the energy demand of a fish, or if low quality protein is used in diet formulation, the amino acids which compound the protein will be used as energy source and high amount of nitrogen will be excreted by deamination of the amino acids in excess. Thus, a low energy to protein ratio could reduce fish growth rates due to the increased metabolic demand of energy to excrete nitrogen and reduces the water quality which is of utmost importance for maintenance of ornamental fish in aquaria. On the other hand, a high energy to protein ratio could lead to increased lipid deposition on body carcass and reduce the nutrient intake leading to deficiency on some nutrients and reduced disease resistance of fish (Cho, 1990). Therefore, the use of proper energy to protein ratios is important when formulating low cost and eco-friendly fish diets.

Several studies have been conducted to evaluate the adequate energy to protein ratio for fish (Webster, 1995; Hernandez et al., 2001; Ai et al., 2004). However, several factors could influence the determination of proper dietary protein to energy ratio, such as fish species and their natural feed habits, size of fish, diet formulation and the production system (Ai et al., 2004; Wang et al., 2013).

Among the ornamental fish species raised in aquaria, the Siamese fighting fish, Betta splendens, is one of the most popular and traded tropical fish. The popularity of $B$. splendens is due to its rusticity and to be a welladapted fish to small containers of water. This fish is among the five most imported ornamental fish by the United States (Chapman et al., 1997; Lima, 2003). Although the economic importance of this fish for the ornamental fish industry, information regarding its nutrient requirements is scant. Thus, based on the importance of protein for fish and the lack of nutritional studies with this B. splendens, we designed an experiment to evaluate the effects of different energy to protein ratios on growth and carcass composition of $B$. splendens and properly recommend the protein and energy level in diets for this species.

\section{MATERIALS AND METHODS}

\section{Experimental diet and diet preparation}

Diets were manufactured using conventional feed ingredients in different proportions aiming to obtain different digestible protein and energy levels (Table 1). Thus, four digestible protein levels $(28.0,35.0,42.0$, and $49.0 \% \mathrm{DP})$ at two digestible energy levels $(3,200$ and $3,600 \mathrm{kcal} / \mathrm{kg}$ DE) were tested comprising eight diets. Digestible protein and energy content of feedstuffs were calculated based on apparent digestibility coefficients reported for $B$. splendens and tilapia (Zuanon et al., 2007; Guimarães et al., 2008).

All ingredients were ground until sieve in a mesh diameter of $500 \mu \mathrm{m}$. Diets were mechanically mixed with water ( $25 \%$ of dry weight) and the moist mixture was extruded in a single screw extruder to obtain $4.0 \mathrm{~mm}$ pellets. Diets were oven dried until present moisture $<100$ $\mathrm{g} / \mathrm{kg}$, and stored at $-18^{\circ} \mathrm{C}$ until further use. At the beginning of the experiment diets were ground and sieved in a mesh diameter according to fish size.

\section{Experimental procedure}

A hundred and twenty all-male B. splendens with approximately 90 days-old were purchased from a commercial ornamental fish farm (Rio de Janeiro, RJ, Brazil) and acclimatized to the laboratory conditions. These fish were fed twice daily with a commercial diet to satiation for two weeks. Water temperature was measured on a daily basis in eight randomly selected tanks, while ammonia and $\mathrm{pH}$ were measured in a weekly basis; accumulated feces were removed by siphoning and the $30 \%$ of the water was replaced daily. Thus, a homogenous group of 56 B.splendens was selected by weight (1.02 $\pm 0.11 \mathrm{~g}$ ) and randomly stocked into $561 \mathrm{~L}$-aquaria at a density of one fish per aquaria. Before weighing, all fish were submitted to a salt bath in a 5\% solution.

Each diet was fed to seven fishes for 30 days. Fish were fed until apparent satiation. Feeding frequency used in this trial was three times daily at 8:00, 12:00, and 16:00 $\mathrm{h}$. During the feeding trial water quality parameters were maintained in the optimum range for fish rearing $(\mathrm{pH}$ $6.8 \pm 0.3$; and ammonia $\left(\mathrm{NH}_{3}\right) 124.0 \mu \mathrm{g} / \mathrm{L}$ ). All tanks were maintained under natural photoperiod.

During the experiment, fish mortality was recorded. At the beginning and at the end of the feeding experiment, fish were starved for $24 \mathrm{~h}$, and then weighed.

\section{Analysis and measurement}

At the end of the experiment each fish was collected and killed with high a megadose of benzocaine $(193 \mathrm{mg} / \mathrm{L})$. 
Two replicates (fish) were polled to compound a sample for chemical analysis and ground in a meat mincer and samples stored frozen $\left(-18^{\circ} \mathrm{C}\right)$ to determine the whole body protein, moisture and energy content. Proximate composition analysis on feed ingredients, experimental diets and fish were performed according to the standard methods of Association of Official Analytical Chemist AOAC (1995). Samples of diets were dried to a constant weight at $105^{\circ} \mathrm{C}$ to determine moisture. Protein was determined by measuring nitrogen $(\mathrm{N} \times 6.25)$ using the

Table 1 - Composition and proximate analysis of the experimental diets.

\begin{tabular}{|c|c|c|c|c|c|c|c|c|}
\hline \multirow[b]{2}{*}{ Ingredients (\%) } & \multicolumn{8}{|c|}{ ED/PD levels } \\
\hline & $\begin{array}{c}3,200 / \\
28.0\end{array}$ & $\begin{array}{c}3,200 / \\
35.0\end{array}$ & $\begin{array}{c}3,200 / \\
42.0\end{array}$ & $\begin{array}{c}3,200 / \\
49.0\end{array}$ & $\begin{array}{c}3,600 / \\
28.0\end{array}$ & $\begin{array}{c}3,600 / \\
35.0\end{array}$ & $\begin{array}{c}3,600 / \\
42.0\end{array}$ & $\begin{array}{c}3,600 / \\
49.0\end{array}$ \\
\hline Soybean meal & 13.65 & 8.00 & - & - & 16.91 & 13.45 & 5.16 & - \\
\hline Cottonseed meal 28 & 15.25 & 16.37 & - & - & 14.41 & 16.15 & 13.72 & - \\
\hline Cottonseed meal 40 & - & - & 7.00 & - & - & - & - & - \\
\hline Corn gluten meal & 8.00 & 8.00 & 14.16 & 15.60 & - & 7.54 & 8.00 & 10.65 \\
\hline Fish meal & 11.70 & 9.50 & - & - & 6.30 & 6.10 & 3.00 & - \\
\hline Poultry by-product meal & 13.92 & 17.50 & 25.64 & - & 25.83 & 15.75 & 28.14 & - \\
\hline Feather meal & - & 10.50 & 20.42 & 47.10 & - & 14.50 & 19.50 & 50.46 \\
\hline Broken rice & 31.00 & 22.16 & 19.00 & 15.30 & 25.00 & 10.10 & 7.00 & 7.10 \\
\hline Gelatin & - & - & - & 4.40 & - & - & - & 5.00 \\
\hline Cellulose & - & - & 5.00 & 6.00 & - & - & 1.70 & 6.30 \\
\hline Lysine-HCl & 1.83 & 2.55 & 3.58 & 2.60 & 1.57 & 1.50 & 2.46 & 3.00 \\
\hline DL - Methionine & 0.70 & 0.70 & 0.77 & 1.12 & 0.40 & 0.30 & 0.75 & 1.12 \\
\hline Tryptophan & 0,41 & 0,60 & 0,14 & 0,05 & 0,04 & 0,04 & 0,05 & 0,06 \\
\hline Threonine & 0.63 & 0.80 & 0.82 & 0.87 & 0.63 & 0.70 & 0.80 & 0.87 \\
\hline Soybean oil & - & - & - & 1.00 & 6.70 & 8.67 & 6.45 & 9.84 \\
\hline Dicalcium phosphate & 1.50 & 1.80 & 1.80 & 2.29 & 1.80 & 3.35 & 1.80 & 1.98 \\
\hline Limestone & 1.00 & 1.11 & 1.26 & 3.26 & - & - & 1.06 & 3.21 \\
\hline Ascorbic acid & 0.04 & 0.04 & 0.04 & 0.04 & 0.04 & 0.40 & 0.04 & 0.04 \\
\hline Salt & 0.10 & 0.10 & 0.10 & 0.10 & 0.10 & 0.10 & 0.10 & 0.10 \\
\hline Vitamin/mineral mix & 0.25 & 0.25 & 0.25 & 0.25 & 0.25 & 0.25 & 0.25 & 0.25 \\
\hline \multirow[t]{2}{*}{$\mathrm{BHT}^{\mathrm{b}}$} & 0.02 & 0.02 & 0.02 & 0.02 & 0.02 & 0.20 & 0.02 & 0.02 \\
\hline & 100 & 100 & 100 & 100 & 100 & 100 & 100 & 100 \\
\hline Digestible energy ${ }^{1,2}$ & $3,269.46$ & $3,258.31$ & $3,173.36$ & $3,210.88$ & $3,637.34$ & $3,608.28$ & $3,623.90$ & $3,599.46$ \\
\hline Digestible protein ${ }^{1,2}$ & 28.60 & 35.64 & 41.76 & 49.02 & 28.26 & 35.22 & 42.25 & 49.02 \\
\hline Crude protein & 34.30 & 42.68 & 49.39 & 55.67 & 32.82 & 42.44 & 49.06 & 55.47 \\
\hline Fiber & 5.32 & 5.11 & 4.50 & 4.74 & 5.08 & 5.31 & 5.62 & 4.87 \\
\hline Lipid & 6.15 & 6.12 & 6.34 & 7.19 & 12.63 & 12.83 & 10.86 & 15.09 \\
\hline
\end{tabular}

${ }^{a}$ Vitamin and mineral premix supplied the following (IU or $\mathrm{mg} / \mathrm{kg}$ diet): vitamin A, 16060; vitamin D3, 4510; vitamin E (DL-a tocopherol), 250; vitamin $\mathrm{K}$ (menadione sodium bisulphite), 30; vitamin B1, 32; vitamin B2 32; Ca-D-pantothenate, 80; niacin, 170; biotin, 10; folic acid, 10; vitamin B12, 32; Na2SeO3, 0.7; $\mathrm{MnO}, 50 ; \mathrm{ZnO}, 150 ; \mathrm{FeSO} 4,150 ; \mathrm{CuSO} 4,20$; $\mathrm{CoSO} 4,0.5$; I2Ca, 1.0. ${ }^{\mathrm{b}}$ Antioxidant: butylated hydroxytoluene.

${ }^{1}$ ADC of protein and energy reported by Guimarães et al. $(2008 \mathrm{a}, \mathrm{b})$ for Nile tilapia; ${ }^{2} \mathrm{ADC}$ of protein and energy reported by Zuanon et al (2007) for B. splendens. 
Kjeldahl method; lipid by ether extraction using Soxhlet; ash by combustion at $550^{\circ} \mathrm{C}$, crude fiber by fritted glass crucible method after treated with $\mathrm{H}_{2} \mathrm{SO}_{4}$ and $\mathrm{NaOH}$, and energy by an adiabatic bomb calorimeter (PARR1281, USA).

\section{Calculations and statistical analysis}

The following variables were calculated:

Specific growth rate $(\mathrm{SGR})=(\mathrm{Ln} F W-\mathrm{Ln}$ IW $) \times 100 / \mathrm{t}$ Weight gain $(\mathrm{WG})=\mathrm{FW}-\mathrm{IW}$

Feed intake $(\mathrm{FI})=$ Feed consumption $(\mathrm{g}) /((\mathrm{FW}+\mathrm{IW}) / 2) \times \mathrm{t})$ Feed conversion ratio $(\mathrm{FCR})=$ Dry feed fed in $\mathrm{g} / \mathrm{wet}$ weight gain in $\mathrm{g}$

Protein efficiency ratio $(\mathrm{PER})=$ Wet weight gain in $\mathrm{g} /$ protein intake in $\mathrm{g}$

where FW is final body weight, IW is initial body weight, $t$ is experimental duration in days.

The experiment followed a completely randomized design arranged in a $2 \times 4$ factorial scheme with seven replicates for growth data and three replicates for whole body chemical composition. Data are presented as means of each treatment (seven or three replicates) with standard deviation. The data were verified for normality (Kolmogorov-Smirnov test) and homogeneity of variances (Levene's $F$ test). Data from each treatment were subjected to one-way analysis of variance (ANOVA), two-way ANOVA and correlation analysis where appropriate. When overall differences were significant $(\mathrm{P}<0.05)$, Schefe multiple range test was used to compare the mean values between individual treatment. Additionally, regression analysis was performed to evaluate the correlation of protein levels in each dietary digestible energy level. Statistical analysis was performed using SAS software (SAS 9.3).

\section{RESULTS AND DISCUSSION}

Growth performance and feed utilization of $B$. splendens fed diets containing different levels of digestible protein and energy over 30-day feeding trial is presented in table 2 .

Regardless the feed intake and protein efficiency ratio (PER), all growth parameters evaluated were not affected $(P>0.05)$ by dietary protein and energy levels, and their interaction. Second order polynomial regression model best fitted to PER at 3,200 kcal/ $\mathrm{kg}$ DE, while linear correlation best fitted to PER values at $3,600 \mathrm{kcal} / \mathrm{kg}$ DE (Figure 1). Fish fed diets containing $42.0 \%$ DP showed the highest FI, irrespective of the dietary energy level, but it was only statistically different from fish fed $35.0 \%$ DP. Only the DP levels influenced FI in this experiment, while DE levels and the interaction between DP and DE did not affect the feed intake of fish.

Table 2 - Growth performance and feed utilization efficiency of Siamese fighting fish fed diets containing different digestible protein and energy levels.

\begin{tabular}{ccccccc}
\hline DP (\%) & \multirow{2}{*}{ DE (kcal/kg) } & FI (g) & WG (g) & FCR & SGR (\%) & PER (\%) \\
\hline 28.0 & & $0.48 \pm 0.09$ & $0.52 \pm 0.08$ & $0.92 \pm 0.12$ & $1.40 \pm 0.19$ & $3.91 \pm 0.48$ \\
35.0 & \multirow{2}{*}{3,200} & $0.46 \pm 0.06$ & $0.47 \pm 0.08$ & $1.04 \pm 0.17$ & $1.24 \pm 0.23$ & $2.92 \pm 0.29$ \\
42.0 & & $0.59 \pm 0.10$ & $0.48 \pm 0.11$ & $1.27 \pm 0.20$ & $1.27 \pm 0.28$ & $1.91 \pm 0.28$ \\
49.0 & & $0.49 \pm 0.06$ & $0.42 \pm 0.10$ & $1.22 \pm 0.27$ & $1.17 \pm 0.30$ & $1.73 \pm 0.32$ \\
\hline 28.0 & & $0.57 \pm 0.06$ & $0.45 \pm 0.11$ & $1.35 \pm 0.36$ & $1.18 \pm 0.21$ & $2.81 \pm 0.72$ \\
35.0 & \multirow{2}{*}{3600} & $0.51 \pm 0.06$ & $0.45 \pm 0.06$ & $1.14 \pm 0.11$ & $1.24 \pm 0.20$ & $2.52 \pm 0.24$ \\
42.0 & & $0.56 \pm 0.03$ & $0.54 \pm 0.05$ & $1.04 \pm 0.14$ & $1.44 \pm 0.15$ & $2.32 \pm 0.33$ \\
49.0 & $0.54 \pm 0.10$ & $0.40 \pm 0.11$ & $1.43 \pm 0.27$ & $1.03 \pm 0.29$ & $1.45 \pm 0.22$ \\
\hline DE & & $\mathrm{ns}$ & $\mathrm{ns}$ & $\mathrm{ns}$ & $\mathrm{ns}$ & $\mathrm{P}<0.01$ \\
DP & & $\mathrm{P}<0.05$ & $\mathrm{~ns}$ & $\mathrm{~ns}$ & $\mathrm{~ns}$ & $\mathrm{P}<0.01$ \\
DE*DP & & $\mathrm{ns}$ & $\mathrm{ns}$ & $\mathrm{ns}$ & $\mathrm{ns}$ & $\mathrm{P}<0.01$ \\
\hline
\end{tabular}

ns - not significant. 

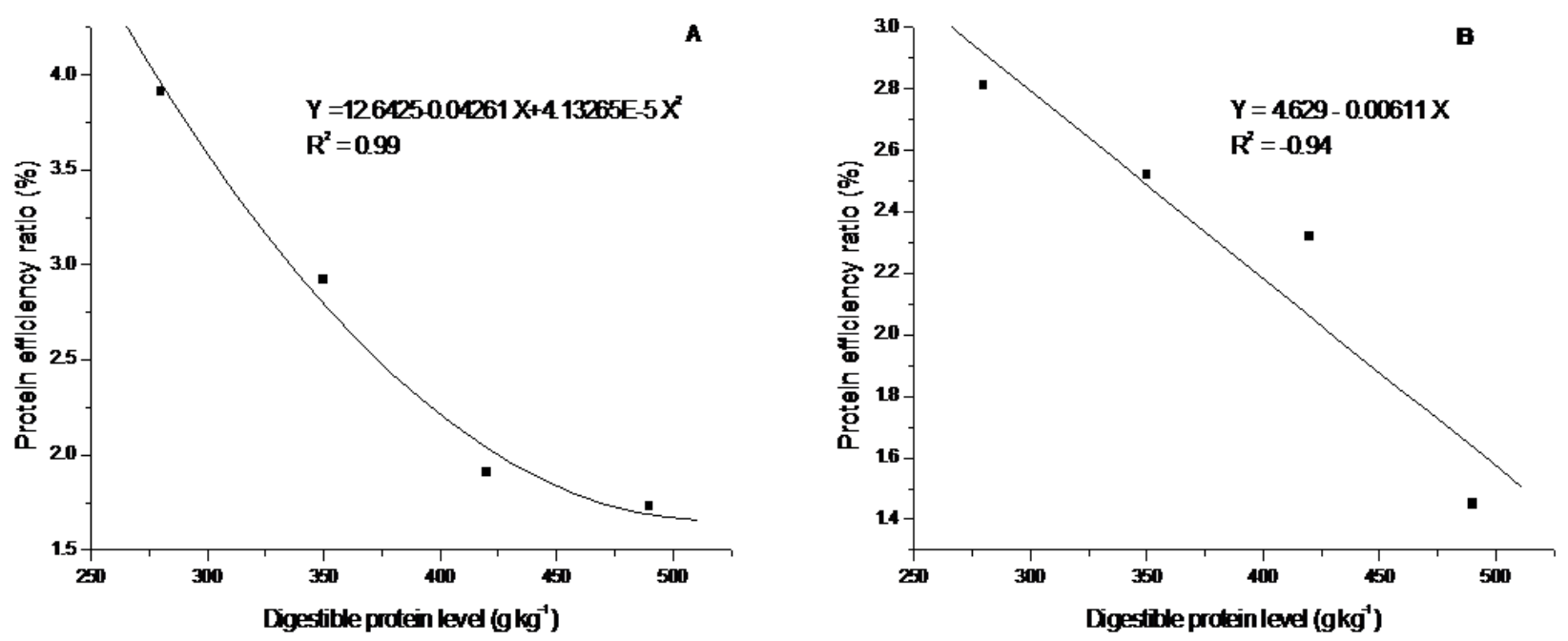

Figure 1 - Effect of dietary protein level on the protein efficiency ratio of Siamese fighting fish fed diets containing 3,200 (A) and 3,600 (B) kcal/kg DE.

Whole body chemical composition of B. splendens fed diets containing different levels of digestible protein and energy over 30-day feeding trial is presented in table 3. All chemical composition variables were affected by dietary protein and energy levels, and their interaction. Fish fed diets containing 3,600 kcal/ $\mathrm{kg}$ DE showed the lowest protein and moisture content in their bodies than fish fed diets with the low DE level. On the other hand, fish fed diets with high DE content showed higher energy content in their bodies. Fish fed diets containing 35.0 and $49.0 \%$ DP at the low DE level showed the highest body protein content, while the lowest protein content was observed in fish fed diets with $42.0 \% \mathrm{DP}$ at the high DE level. The highest body gross energy content was observed in fish fed diets containing $49.0 \% \mathrm{DP}$ and $3,600 \mathrm{kcal} / \mathrm{kg}$ DE. The highest moisture content was observed in fish fed diets containing 28.0 and $49.0 \%$ DP at the low DE level, while the lowest moisture content was observed in fish fed diets containing 35.0 and $49.0 \%$ DP at the high DE level.

Siamese fighting fish is one of the most studied ornamental fish species in the scientific literature being used as a fish model in physiological and behavioral studies (Haller; Wittenberger, 1988; Dzieweczynski; Lyman; Poor, 2009; Puello-Cruz et al., 2010). Additionally, this fish is one of the most common species used as pets and which hobbits have been using to develop new varieties for the ornamental fish market. Although the importance of this fish, there is a lack of studies regarding it is nutritional requirements. Until we could reference, there is just one study which reports the protein requirement for female B. splendens (James; Sampath, 2003); however a proper design of that study is needed since several factors could have influenced the results. In the present study, diets with different digestible protein and energy levels were fed to male $B$. splendens and their effects on growth performance and whole-body chemical composition were investigated.

Results showed that growth of male B. splendens seemed not be affected by both dietary protein and energy levels; surprisingly, only dietary protein level affected feed intake in this study. Dietary energy is one of the main factors postulated to influence feed intake in fish (Grove; Lozoides; Nott, 1978; Boujard; Médale, 1994). There is evidence to suggest that fish control feed intake primarily to meet energy needs, and that control is closer related to the digestible and metabolisable energy of the diet (Morales et al., 1994). Although there are basis which supports the hypothesis that fish are able to control feed intake to meet energy requirements, many studies which observed this effect was diluted by indigestible bulk, such as cellulose or carboxi methyl cellulose. According to De La Higuera (2001), it is important to know whether fish regulate their feed intake primarily on the basis of energy concentration or whether there is a separate regulation of individual nutrients or nutrient groups, i.e. macronutrients (proteins, lipids and carbohydrates) and micronutrients (vitamins and minerals). Thus, it seems that $B$. splendens regulates feed intake based on the source of protein than the amount of protein, indicating 
that this species are more prone to ingest food based on organoleptic characteristics. This hypothesis is supported by the increased feed intake observed in fish fed diets containing $42.0 \%$ DP irrespective of DE level. There are strong evidences in literature to support our hypothesis, since previous results have indicated that essential amino acid profile and concentration may affect feed intake of fish (García-Gallego; Akharback; De La Higuera, 1998; Médale et al., 1998; De La Higuera et al., 1998, 1999). Thus, based on the assumption that animal proteins are generally richer in essential amino acid and their profile is more similar to the requirement of fish than plant proteins, the diets containing high percentage of animal proteins may have increased feed intake of $B$. splendens.

The growth and feed utilization of Siamese fighting fish were not affected by dietary protein and energy levels, indicating that the level of $28.0 \% \mathrm{DP}$ and 3,200 kcal $/ \mathrm{kg}$ DE may be sufficient to meet protein and energy requirements, respectively, for this species. This result is supported by PER values observed in this study which tended to reduce according to the increase of protein levels. Additionally, fish fed high energy diets showed reduced protein utilization irrespective of dietary protein levels. There are evidences which has proven that a decrease in DP:DE ratio is extremely efficient in improving protein utilization and decrease nitrogenous losses in several farmed fish species (National Research Council - NRC, 2011). Although this protein sparing effect of non-protein energy sources has been shown in several species, we could not observe this effect in Siamese fighting fish. However, our results are in one hand with reports in other fish species, such as rainbow trout (Oncorhynchus mykiss), chinook salmon (Oncorhynchus tshawytscha), turbot (Scophthalmus maximus), sea bass (Dicentrarchus labrax), tench (Tinca tinca) and mulloway (Argyrosomus japonicas) (Peres; Oliva-Teles, 1999; De Pedro et al., 2001; Regost et al., 2001; Azevedo et al., 2004; Pirozzi; Booth; Allan, 2010). According to some authors, an absence of protein sparing effect from non-protein energy sources may be attributable to (1) a limited feed intake in high energy diets or (2) a preferable use of amino acids as energy source in metabolism of some species (Rasmussen et al., 2000; Azevedo et al., 2004). However, the first hypothesis may be unlikely in Siamese fighting fish since only protein sources affected feed intake in this study; on the other side, further metabolic studies is needed to confirm the second hypothesis. Additionally, considering that the protein requirement for this species was relatively low compared to other farmed and ornamental fish species, it is already unlikely that Siamese fighting fish utilizes proteins/amino acids as a preferable energy source.

Although the dietary protein and energy levels did not affect the growth and feed utilization of male Siamese fighting fish, both factors and their interaction influenced whole body composition of fish. It is a common sense in most of the reports that the increase of dietary lipids is usually associated with an increase on whole body lipid content (Peres; Oliva-Telles, 1999; Regost et al., 2001;

Table 3 - Whole body chemical composition of Siamese fighting fish fed diets containing different digestible protein and energy levels.

\begin{tabular}{cccccc}
\hline DP (\%) & DE (kcal/kg) & Crude protein (\%) & Gross energy (cal/g) & Moisture (\%) & Dry matter (\%) \\
\hline 28.0 & & $13.45 \pm 0.43 \mathrm{ac}$ & $5218.55 \pm 38.55 \mathrm{bcd}$ & $77.33 \pm 1.03 \mathrm{a}$ & $22.66 \pm 1.03 \mathrm{bc}$ \\
35.0 & \multirow{2}{*}{3,200} & $14.41 \pm 0.46 \mathrm{ab}$ & $5304.85 \pm 18.46 \mathrm{abc}$ & $73.50 \pm 2.14 \mathrm{ab}$ & $26.50 \pm 2.14 \mathrm{abc}$ \\
42.0 & & $13.29 \pm 0.25 \mathrm{~cd}$ & $4916.83 \pm 104.60 \mathrm{e}$ & $72.79 \pm 2.33 \mathrm{ab}$ & $27.20 \pm 2.33 \mathrm{abc}$ \\
49.0 & & $14.59 \pm 0.32 \mathrm{~b}$ & $5024.27 \pm 14.22 \mathrm{de}$ & $78.26 \pm 1.58 \mathrm{a}$ & $21.74 \pm 1.58 \mathrm{c}$ \\
\hline 28.0 & & $12.82 \pm 0.28 \mathrm{~cd}$ & $5161.64 \pm 29.99 \mathrm{~cd}$ & $72.65 \pm 1.16 \mathrm{ab}$ & $27.34 \pm 1.16 \mathrm{ab}$ \\
35.0 & \multirow{2}{*}{3,600} & $13.10 \pm 0.01 \mathrm{~cd}$ & $5416.02 \pm 49.19 \mathrm{ab}$ & $69.57 \pm 0.19 \mathrm{~b}$ & $30.43 \pm 0.19 \mathrm{a}$ \\
42.0 & & $12.19 \pm 0.37 \mathrm{~d}$ & $5178.49 \pm 0.42 \mathrm{~cd}$ & $73.61 \pm 2.55 \mathrm{ab}$ & $27.37 \pm 1.37 \mathrm{ab}$ \\
49.0 & & $12.56 \pm 0.17 \mathrm{~cd}$ & $5453.73 \pm 99.92 \mathrm{a}$ & $70.58 \pm 1.81 \mathrm{~b}$ & $29.41 \pm 1.81 \mathrm{a}$ \\
\hline ED & & $\mathrm{P}<0.01$ & $\mathrm{P}<0.01$ & $\mathrm{P}<0.01$ & $\mathrm{P}<0.01$ \\
PD & & $\mathrm{P}<0.01$ & $\mathrm{P}<0.01$ & $\mathrm{P}<0.05$ & $\mathrm{P}<0.01$ \\
ED*PD & & $\mathrm{P}<0.05$ & $\mathrm{P}<0.01$ & $\mathrm{P}<0.01$ & $\mathrm{P}<0.01$ \\
\hline
\end{tabular}

Different superscript letters within a column indicate significant differences at $\mathrm{P}<0.05$ by Schefee test. 
Pirozzi et al., 2010). Although we did not perform the lipid analysis in our study due to the lack of samples and size of the fish, we could hypothesize that the high energy content observed in fish fed the high energy diets may be a response of an increase in whole body lipid levels since the protein content in these fish were lower than those fed diets with low energy levels, and the carbohydrate content in fish muscle is low and hardly modulated by dietary factors (Sanchez-Muros et al., 1996; Shul'man, 1974; Wilson, 1994). Additionally, an inverse correlation between energy concentration and, protein and moisture content supports that hypothesis since increase lipid levels in animals carcass is usually associated with reduction of protein and moisture levels (Page; Andrews, 1973).

The highest protein content observed in Siamese fighting fish fed diets containing 35.0 and $49.0 \%$ DP at $3,200 \mathrm{kcal} / \mathrm{kg}$ supports the PER results which the low DE level resulted in improved PER values. Thus, based on highest protein utilization, this DE level and the $35.0 \%$ DP must be more appropriate levels of energy and protein, respectively, for this ornamental fish. On this regard, we could assume that at this DE level a higher protein requirement was observed for protein retention compared with for highest growth rates. This result is in accordance to reports with other farmed and ornamental fish species which observed a higher estimated protein requirement for maximum protein retention than to maximize growth performance (Page; Andrews, 1973; Catacutan; Coloso, 1995; Schulz, 2008).

Although the estimated protein requirement is a basic information for aquaculture industry in the scientific literature, the information pertaining this basic information for ornamental fish species is scant. A few reports have been reporting estimated protein requirements for the gourami's family, which includes the male Siamese fighting fish and other species of other genus. These reports have estimated the protein requirement to be around $350 \mathrm{~g} / \mathrm{kg}$ (Shim et al., 1989; Degani; Gu, 1992); however several with experimental design and diet formulation are observed in those studies which difficult the comparison among studies. We observed a lower protein requirement for maximum weight gain in male Siamese fighting fish in this study; on the other side, a higher requirement for maximum carcass protein deposition was observed in this study. Additionally, it seems that $B$. splendens is more prone to regulate the ingestion of food based on protein source than the DE level; however further studies are required to confirm our hypothesis since feeding male Siamese fighting fish is a difficult task and a high degree of variation according to each individual fish may imply in some level of error.

\section{CONCLUSION}

This study demonstrated that in our experimental conditions the estimated protein requirement for male Siamese fighting fish must be between 28.0 and $35.0 \%$ and the proper DE level is $3,200 \mathrm{kcal} / \mathrm{kg}$ DE or a dietary protein to energy ratio between 87.5 - 109 $\mathrm{mg} / \mathrm{kcal} \mathrm{DE}$.

\section{ACKNOWLEDGMENTS}

We are grateful to Dr. Barros and Dr. Pezzato for their support on processing the experimental diets in their laboratory at Universidade Estadual Paulista Júlio de Mesquita Filho.

\section{REFERENCES}

AI, Q. et al. Effects of dietary protein to energy ratios on growth and body composition of juvenile Japanese seabass, Lateolabrax japonicas. Aquaculture, 230(1):507-516, 2004.

\section{ASSOCIATION OF OFFICIAL ANALYTICAL} CHEMIST - AOAC. Official methods of analysis of the association of official analytical chemists. Arlington v.2, p.1-30, 1995.

AZEVEDO, P.A. et al. Growth, nitrogen and energy utilization of juveniles from four salmonid species: diet, species and size effects. Aquaculture, 234(1-4):393414, 2004.

BLOM, J.H.; DABROWSKI, K. Vitamin C requirements of the angelfish Pterophylum scalare. Journal of the World Aquaculture Society, 31(1):115$118,2000$.

BOUJARD, T.; MÉDALE, F. Regulation of voluntary feed intake in juvenile rainbow trout fed by hand or by self-feeders with diets containing two different protein/ energy ratios. Aquatic Living Resources, 7(3):211-215, 1994.

CATACUTAN, M.R.; COLOSO, R.M. Effect of dietary protein to energy ratios on growth, survival, and body composition of juvenile Asian seabass, Lates calcarifer. Aquaculture, 131(1-5):125-133, 1995.

CHAPMAN, F.A. et al. United States of America trade in ornamental fish. Journal of the World Aquaculture Society, 1(28):1-10, 1997. 
CHO, C.Y. Fish nutrition, feeds, and feeding: with special emphasis on salmonid aquaculture. Food Reviews International, 6(3):333-357, 1990.

DEGANI, G.; GUR, N. Growth of juvenile Trichogaster leerii (Bleeker, 1852) on diets with various protein levels. Aquaculture and Fishery Management, 23(2):161-166, 1992.

DE LA HIGUERA, M. et al. Influence of temperature and dietary-protein supplementation either with free or coated lysine on the fractional protein-turnover rates in the white muscle of carp. Fish Physiology and Biochemistry, 18(1):85-95, 1998.

DE LA HIGUERA, M. et al. Liver and white muscle protein turnover rates in the European eel (Anguilla anguilla): effects of dietary protein quality. Aquaculture, 179(1):203-216, 1999.

DE LA HIGUERA, M. Effects of nutritional factors and feed characteristics on feed intake. In: HOULIHAN, D.; BOUJARD, T.; JOBLING, M. Food intake in fish. Willey-Blackwell, 2001. p. 250-268.

DE PEDRO, N. et al. Influence of dietary composition on growth and energy reserves in tench (Tinca tinca). Journal of Applied Ichthyology, 17(1):25-29, 2001.

DZIEWECZYNSKI, T.L.; LYMAN, S.; POOR, E.A. Male Siamese fighting fish, Betta splendens, increase rather than conceal courtship behavior when a rival is present. Ethology, 115(2):186-195, 2009.

EL-SAYED, A.M.; TESHIMA, S.I. Protein and energy requirements of Nile tilapia, Oreochromis niloticus, fry. Aquaculture, 103(1):55-63, 1992.

\section{FOOD AND AGRICULTURE ORGANIZATION} OF THE UNITED NATIONS - FAO. The State of World Fisheries and Aquaculture 2006. FAO Fisheries and Aquaculture Department, FAO. Rome, 2007. p. 162.

GARCÍA-GALLEGO, M.; AKHARBACH, H.; DE LA HIGUERA, M. Use of protein sources alternative to fish meal in diets with amino acids supplementation for the European eel (Anguilla anguilla). Animal Science, 66(1):285-292, 1998.
GARLING JUNIOR, D.L.; WILSON, R.P. The optimum protein-to-energy ratio for channel catfish, lctalurus puactatus. Journal of Nutrition, 106(1):13681375, 1976.

GROVE, D.J.; LOZOIDES, L.; NOTT, J. Satiation amount, frequency of feeding and gastric emptying rate in Salmo gairdneri. Journal of Fish Biology, 14(2):53946, 1978 .

GUIMARÃES, I.G. et al. Nutrient digestibility of cereal grain products and by-products in extruded diets for Nile tilapia. Journal of the World Aquaculture Society, 39(6):781-789, 2008.

HALLER, J.; WITTENBERGER, C. Biochemical energetics of hierarchy formation in Betta splendens. Physiology Behavior, 43(4):447-450, 1988.

HERNANDEZ, M.D. et al. Effects of commercial diets with different $\mathrm{P} / \mathrm{E}$ ratios on sharpsnout seabream (Diplodus puntazzo) growth and nutrient utilization. Aquaculture, 195(1):321-329, 2001.

JAMES, R.; SAMPATH, K. Effect of animal and plant protein diets on growth and fecundity in ornamental fish, Betta splendens (REGAN). The Israeli Journal of Aquaculture, 55(1):39-52, 2003.

LIMA, A.O. Aquicultura ornamental: O potencial de mercado para algumas espécies ornamentais. Formas alternativas de diversificação da produção na aqüicultura brasileira. Panorama da Aquicultura, 13(1):23-29, 2003.

MÉDALE, F. et al. Voluntary feed intake, nitrogen and phosphorus losses in rainbow trout (Oncorhynchus mykiss) fed increasing dietary levels of soy protein concentrate. Aquatic Living Resources, 11(4):239-246, 1998.

MORALES, A.E. et al. Effects of dietary protein source on growth, feed conversion and energy utilization in raibow trout, Oncorhynchus mykiss. Aquaculture, 124(1):117-126, 1994.

NATIONAL RESEARCH COUNCIL - NRC. Nutrient requirements of fish and shrimp. National Academy Press, Washington, DC, USA, 2011. 
PAGE, J.W.; ANDREWS, J.W. Interactions of dietary levels of protein and energy on channel catfish (Icfalurus punctatus). Journal of Nutrition, 103(1):1339-1346, 1973.

PANNÉ, H.S.; LUCHINI, L. Panorama actual del Comercio Internacional de peces ornamentales.

Dirección de acuicultura, Argentina, 2008.

PERES, H.; OLIVA-TELES, A. Effect of dietary lipid level on growth performance and feed utilization by European sea bass juveniles (Dicentrarchus labrax). Aquaculture, 179(1):325-334, 1999.

PIROZZI, I.; BOOTH, M.A.; ALLAN, G.L. The interactive effects of dietary protein and energy on feed intake, growth and protein utilization of juvenile mulloway (Argyrosomus japonicus). Aquaculture Nutrition, 16(1):61-71, 2010.

PUELLO-CRUZ, A.C. et al. Growth and survival of Siamese fighting fish, Betta splendens, larvae at low salinity and with different diets. Journal of World Aquaculture Society, 41(5):823-828, 2010.

RASMUSSEN, R.S.; OSTENFELD, T.H.; MCLEAN, E. Growth and feed utilization of rainbow trout subjected to changes in feed lipid concentrations. Aquaculture International, 8(1):531-542, 2000.

REGOST, C. et al. Dietary lipid level, hepatic lipogenesis and flesh quality in turbot (Psetta maxima). Aquaculture, 193(3-4):291-309, 2001.

ROBINSON, E.H.; LI, M.H. Low protein diets for channel catfish Icatalurus punctatus raised in earthen ponds at high density. Journal of the World Aquaculture Society, 28(3):224-229, 1997.

SALES, J.; JANSSENS, G.P.J. Nutrient requirements of ornamental fishes. Aquatic Living Resources, 16(6):533-540, 2003.
SÁNCHEZ-MUROS M.J. et al. Long-term nutritional effects on the primary liver kidney metabolism in rainbow trout (Oncorhynchus mykiss). 2. Adaptative response of glucose 6-phosphate dehydrogenase activity to high-carbohydrate/low-protein and high-fat/noncarbohydrate diets. Aquaculture Nutrition, 2(4):193200, 1996.

SCHULZ, C. et al. Effects of varying dietary protein to lipid ratios on growth performance and body composition of juvenile pike perch (Sander lucioperca). Aquaculture Nutrition, 14(2):166-173, 2008.

SHIM K.F.; LANDESMAN, L.; LAM, T.J. Effect of dietary protein on growth, ovarian development and fecundity in the dwarf gourami Colisa lalia (Hamilton). Journal of Aquaculture in the Tropics, 4(1):111-123, 1989.

SHUL'MAN, G.E. Life Cycles of Fish. Wiley, New York. 1974. p. 327.

WANG, Y.Y. et al. Effects of dietary protein and lipid levels on growth, feed utilization and body composition in Pseudobagrus ussuriensis fingerlings. Aquaculture nutrition, 19(3):390-398, 2013.

WEBSTER, C.D. et al. Effects of dietary protein and lipid levels on growth and body composition of sunshine bass (Morone chrysops x Morone saxatilis) reared in cages. Aquaculture, 131(1):291-301, 1995.

WILSON, R.P. Utilization of dietary carbohydrate by fish. Aquaculture, 124(1-4):67-80, 1994.

YANONG, R.P.E. Nutrition of ornamental fish. Husbandry and Nutrition, 2(1):19-41, 1999.

ZUANON, J.A.S. et al. Digestibilidade de alimentos protéicos e energéticos para fêmeas de beta. Revista Brasileira Zootecnia, 36(4):987-991, 2007. 